\title{
PENGENALAN RUANG SEJARAH (HISTORY ROOM) SEBAGAI MEDIA PEMBELAJARAN SEJARAH BAGI PENDIDIK DI KOTA METRO
}

\author{
Bobi Hidayat \\ Program studi pendidikan sejarah FKIP Universitas Muhammadiyah Metro \\ Email: hidayat_bobi@yahoo.com
}

\begin{abstract}
Abstrak
Ruang sejarah merupakan komponen yang penting dalam proses pembelajaran sejarah. Ruang sejarah akan dapat mampu menopang guru dalam memahamkan kesadaran sejarah siswa. Namun demikian, pemanfaatan ruang sejarah oleh guru dalam proses pembelajaran masih dinilai kurang disebabkan karena keberadaan ruang sejarah yang terbatas. Keterbatasan ini yang menjadi kendala guru sehingga perlu adanya pengenalan dalam mengelola dan memanfaatkan ruang sejarah sebagai media pembelajaran sejarah yang berujung pada peningkatan kesadaran sejarah siswa. Metode yang digunakan untuk mengenalkan ruang sejarah (history room) dengan ekspositori dan diskusi. Kedua metode ini dipilih dengan asumsi sebagai langkah awal yang disebabkan karena guru sejarah masih kurang informasi tentang pemanfaatan ruang sejarah (history room) sebagai media pembelajaran sejarah. Hasil yang diperoleh dalam kegiatan ini adalah terjadinya peningkatan pemahaman guru tentang ruang sejarah (history room). Pemahaman terhadap ruang sejarah (history room) berdampak pada keinginan guru untuk mengembangkan dan memanfaatkan ruang sejarah (history room) sebagai media pembelajaran sejarah. Meski demikian terdapat kendala yang muncul dalam upaya mengadakan ruang sejarah (history room) di sekolah diantaranya masalah dukungan dari sekolah yang diupayakan penyelesaianya dengan cara melakukan pendekatan komunikasi dengan penentu kebijakan di sekolah.
\end{abstract}

Kata Kunci: Media Pembelajaran dan Ruang Sejarah

\begin{abstract}
The history room is the important component in history teaching learning process. The history room can assist the teacher in giving a deep understanding about the student history awareness. But, in this case the using of history room by the teacher in teaching learning process isn't optimal because of the room is limited. The limitation craeted some problem to the teacher so the socialization in managing and using the history room as a media in teaching and learning history was needed; and in the end hopefully the student history awareness can be improved. The methods used to introduce the history room were explanation and discussion. The methods choosed as the first step because most of the teacher didn't have enough information in using the history room as the media in teaching and learning history. The result of this activity showed that the teacher understanding about history room improved. The understanding caused the teacher had a willing in developing and using the history room as a media in teaching and learning history. Although, there were some obstacles appeared in applying the history room in school, one of them was the support from the school but the communication with the school decision maker will be done to solve it.
\end{abstract}

Key words: teaching learning media and history room

\section{PENDAHULUAN}

Pembelajaran sejarah merupakan pembelajaran yang berorientasi pada pemahaman siswa terhadap materi sejarah yang dipelajari sehingga dapat membangkitkan dan mengembangkan serta memelihara semangat kebangsaan (Ali, 2005: 351). Hal ini menuntut profesionalisme seorang guru sebagai penyampai materi sejarah. Kompetensi itu meliputi pedagogik, kepribadian, profesional, dan sosial. Salah satu 
kompetensi yang menuntut guru menguasai konsep dibidangnya adalah komptensi profesional. Kompetensi ini mendorong guru untuk menguasai konsep dibidangnya secara mendalam (Hidayat, 2015: 61).

Selama ini, guru masih terjebak pada perannya sebagai penyampai informasi atau transfer of knowledge (Supriatna, 2007: 174) dan melupakan tugasnya sebagai pendidik yang bertugas mengubah sikap dan tingkah laku (transform).

Tidak sebatas itu, dalam mempelajari sejarah guru juga harus dapat menghantarkan siswanya untuk memiliki kesadaran sejarah dimana siswa mampu menghayati pentingnya nilai-nilai yang dapat diambil pada peristiwa sejarah yang dipelajari. Guna memperdalam kesadaran siswa tentang peristiwa sejarah yang dipelajari guru memiliki peranan yang penting. Namun, disisi lain guru juga mengalami kesulitan dalam membantu siswa untuk mewujudkan kesadaran sejarah. Hal ini dipengaruhi dari konsep atau materi sejarah yang cenderung abstrak karena sebagian besar melibatkan imajinasi pembelajarnya untuk merekonstruksi peristiwa dan mengambil pelajaran darinya. Akibatnya guru mengajarkan sejarah dengan ceramah mengulangi apa isi yang ada dalam buku (Anggara, 2007: 102). Hal ini yang menjadi salah satu kendala guru dalam mengelola proses pembelajaran sejarah dan guru mengalami kesulitan untuk menunculkan kesadaran sejarah pada diri siswa.

Permasalahan di atas memerlukan penyelesaian yang baik seperti mengupayakan media pembelajaran sejarah yang dapat menjembatani permasalahan yang dihadapi baik oleh siswa maupun guru. Media pembelajaran yang diperlukan atau dapat digunakan dalam proses pembelajaran salah satunya adalah ruang sejarah (history room). Pemanfaatan ruang sejarah sebagai media pembelajaran perlu diketahui oleh guru dan siswa sehingga ruang sejarah dapat digunakan sebagai media pembelajaran sejarah yang mampu mengkonversi dari hal yang abstrak ke hal yang lebih kongkret. Sesuai dengan salah satu tujuan pemanfaatan media yaitu membuat hal yang abstrak menjadi hal yang lebih kongkret dan dapat diterima oleh siswa. Media pembelajaran juga dapat mengatasi jurang pemisah antara pembelajar dan sumber belajar (Midun dalam Hamid, 2014: 59)

Salah satu yang dapat dimanfaatkan sebagi media pembelajaran sejarah adalah ruang sejarah (history room). Menurut Widja (1989: 70) Ruang sejarah (history room) adalah sebuah ruangan khusus yang merupakan tempat peragaan dan pemantapan pelajaran sejarah ( $a$ living centre of the study of history). Ruang sejarah dapat didesain sedemikian rupa sehingga dapat memberikan 
gambaran yang nyata akan peristiwa sejarah bagi penggunanya. Setelah memanfaatkan ruang sejarah, Pembelajar dimungkinkan akan lebih mantap dalam mempelajari konsep sejarah sehingga kesadaran sejarah akan muncul. Sehingga tidak menutup kemungkinan di sekolah disediakan ruang khusus untuk belajar sejarah, seperti yang diungkapkan oleh C.P. Hill dalam Kochhar (2008:374) bahwa sejarah merupakan mata pelajaran yang menggunakan tekniknya sendiri, dari sudut pandang itu cukup adil apabila sejarah membutuhkan ruangan tersendiri untuk digunakan secara efektif. Hal ini mendorong perlunya ruang sejarah di sekolah.

Namun berbeda dengan kenyataan di sekolah, ruang sejarah (history room) yang tersedia di sekolah khususnya SMA di Kota Metro masih sangat terbatas. Bahkan berdasarkan dari pengamatan penulis, belum ada sekolah yang memiliki ruang sejarah (history room) yang khusus disediakan untuk penunjang pembelajaran sejarah. Sekolah belum sepenuhnya memfasilitasi guru sejarah utuk mengembangkan proses pembelajaran.

Oleh karena itu perlu adanya pengenalan kepada guru sejarah khususnya guru sejarah SMA di Kota Metro akan pentingnya pengetahuan dan perlunya ruang sejarah di sekolah sebagai media pembelajaran sejarah guna membantu meningkatkan kesadaran sejarah siswa.

\section{METODE PENELITIAN}

Pengenalan ruang sejarah (history room) kepada guru sejarah di Kota Metro dilakukan dengan menggunakan metode ekspositori dan diskusi. Ekspositori dilakukan dengan cara memberikan penjelasan dan pemaparan kepada guru atau pendidik tentang konsep ruang sejarah (history room) sebagai media pembelajaran sejarah. Sedangkan metode diskusi digunakan sebagai wahana untuk menggali potensi dan masalah lain yang dihadapi oleh guru sejarah dalam mewujudkan dan memanfaatkan ruang sejarah (history room) di Sekolah. Melalui kedua metode ini, diharapkan dapat meawadahi guru dalam upaya meningkatkan pemahaman tentang pemanfaatan ruang sejarah dan pada akhirnya dapat meningkatkan kesadaran sejarah siswa melalui pemanfaatan ruang sejarah dalam pembelajaran.

Ruang sejarah (history room) salah satunya bermanfaat untuk mengkonversi konsep atau materi sejarah yang bersifat abstrak menjadi lebih kongkret.

\section{HASIL DAN PEMBAHASAN}

Pelaksanaan pengenalan ruang sejarah kepada guru SMA di Kota Metro dilakukan dengan cara mengundang guru sejarah pada tataran SMA se-Kota Metro ke Program Studi Pendidikan Sejarah yang 
ditempatkan di Laboratorium Sejarah. Berdasarkan hasil dilapangan guru yang datang berjumlah 8 orang yang kesemuanya berasal dari sekolah SMA Negeri di Kota Metro. Pelaksanaan pengenalam diawali dengan menyajikan atau penyampaian materi tentang posisi sejarah saat ini kepada guru.

Posisi sejarah saat ini adalah banyaknya materi dengan jumlah waktu belajar yang sedikit. Jika waktu ditambah materi pelajaran sejarah yang juga ditambah. Disisi lain belajar sejarah saat ini tidak dapat dipahami sebagai hafalan materi, akan tetapi dimaknai untuk kemudian diambil pelajaranya. Dengan kata lain pendidikan sejarah merupakan pendidikan nilai. Melalui pengetahuan tentang pososisi sejarah saat ini diharapkan akan dapat mendorong semangat guru dalam mengembangankan keilmuanya. Pemilihan materi ini disebabkan karena pemahaman sejarah guru saat ini yang dipandang masih perlu ditingkatkan.

Kemudian disampaikan tentang media pembelajaran sejarah dimana media pembelajaran sejarah yang dapat digunakan guru sangat bervariasi. Media pembelajaran sangat penting bagi Guru untuk dapat digunakan oleh guru guna meningkatkan kesadaran sejarah karena siswa diharapkan dapat mengambil pelajaran dari belajar sejarah melalui pemanfaatan media pembelajaran.
Kemudian yang terakhir adalah penyampaian materi tentang ruang sejarah (history room) yang dilakukan di ruang sejarah Program Studi Pendidikan Sejarah FKIP UM Metro.

Ruang sejarah merupakan ruangan untuk mewujudkan panggung secara makro dan sekaligus untuk mengambil makna abadi dari pelajaran yang diberikan oleh sejarah untuk masa kini dan untuk waktu yang akan datang. Ruang sejarah bukanlah semata-mata berfungsi untuk meragakan benda-benda sejarah seperti halnya museum, tapi lebih dari itu, ini adalah suatu tempat pemantapan pelajaran sejarah sebab didalamnya termasuk juga kegiatankegiatan yang memungkinkan siswa menghayati arti sejarah secara mendalam.

Ruang sejarah (history room) di sampaikan selain berupa konsep, juga sekaligus memberikan gambaran secara nyata pada guru sejarah tentang bentuk ruang sejarah (history room) yang dapat dijadikan media pembelajaran sejarah.

Program Studi Pendidikan Sejarah UM Metro memiliki ruang sejarah yang juga dapat dimanfaatkan oleh guru dan siswa dari sekolah sebagai media pembelajaran. Selain diberikan konsep ruang sejarah (history room), guru juga langsung dapat melihat contoh ruang sejarah (history room). 
Hasil yang dicapai adalah pengetahuan dan pemahaman guru tentang pentingnya ruang sejarah (history room) sebagai pendukung proses belajar siswa mengalami peningkatan. Pemahaman guru tentang media pembelajaran dengan memanfaatkan ruang sejarah bertambah sehingga guru terdorong dan berkeinginan mewujudkan ruang sejarah di sekolah masing-masing.

Kemudian dilanjutkan dengan sesi diskusi sebagai wahana untuk menggali permasalahan yang dihadapi guru dalam memanfaatkan ruang sejarah (history room). Dari hasil diskusi dengan guru sejarah didapat beberapa kendala yang dihadapi guru dalam memanfaatkan ruang sejarah (history room) sekaligus kendala guru dalam mewujudkan ruang sejarah (history room) di sekolah. Kendala yang dihadapi guru antara lain:

1. Terbatasnya sarana dan prasarana di sekolah. Ruang kelas yang terbatas, menyebankan sulitnya guru untuk pengadaan ruang sejarah (history room) sebagai media pembelajaran sejarah di sekolah.

2. Pemangku kebijakan sekolah yang kurang memahami tentang pentingnya pengadaan ruang sejarah (meskipun ruang kelas masih ada, namun tidak diijinkan digunakan sebagai ruang sejarah karena dipandang tidak penting oleh kepala sekolah).
Hal ini menunjukkan bahwa pemahaman tentang konsep sejarah bagi pemangku kebijakan menjadi penting, sehingga keperluan tentang ruang sejarah (history room) di sekolah dapat diwujudkan.

3. Masih minimnya pemahaman guru sejarah tentang bagaimana mengelola ruang sejarah (history room) sehingga berdampak pada belum perlunya ruang sejarah (history room) untuk pembelajaran. Munculnya kondisi ini yang juga menjadi dasar dalam mengadakan kegiatan ini.

Sesi diskusi juga menghasilkan rencana solusi dalam mengatasi permasalan yang muncul. Solusi yang didapat dari hasil diskusi tidak terlepas dari bertambahnya pemahaman guru tentang pentingnya ruang sejarah (history room). Pemahaman ini, akan menambah semangat guru dalam mengadakan dan memperjuangkan ruang sejarah (history room) di sekolah. Pemahaman yang didapat juga dapat dijadikan dasar guru untuk menyampaikan pendapat kepada kepala sekolah akan pentingnya ruang sejarah. Secara terperinci solusi yang didapat pada sesi diskusi adalah sebagai berikut:

1. Pendekatan dengan kepala sekolah akan terus diupayakan guru sejarah agar dapat mewujudkan ruang sejarah (history room) di sekolah. 
2. Akan dilakukan pertemuan lanjutan dengan guru sejarah sebagai upaya peningkatan pemahaman mengenai ruang sejarah (history room).

3. Keterbukaan ruang sejarah (history room) FKIP UM Metro yang dalam hal ini Laboratorium Sejarah FKIP UM Metro dapat terbuka untuk umum sebagai wahana untuk belajar baik kalangan dosen, mahasiswa, guru sejarah maupun siswa.

Berdasarkan hasil pertemuan dengan guru sejarah SMA se-Kota Metro, dapat memberikan hasil bahwa pemahaman guru tentang ruang sejarah (history room) masih minim dan perlu ditingkatkan kembali. Selain itu, guru sejarah juga dapat memanfaatkan ruang sejarah di Program Studi Pendidikan sejarah sebagai wahana belajar siswa yang pada akhirnya dapat membantu guru dalam upaya meningkatkan kesadaran sejarah siswa.

\section{PENUTUP}

\section{Kesimpulan}

Berdasarkan pembahasan dapat diambil kesimpulan bahwa, ruang sejarah sangat diperlukan untuk menunjang proses pembelajaran sejarah di sekolah.

Selam ini, pemahaman guru sejarah tentang ruang sejarah (history room) masih terbatas sehingga perlu ditingkatkan. Peningkatan dapat sampai pada pengelolaan dan pemanfaatan ruang sejarah (history room) sebagai media pembelajaran sejarah. Meski demikian sudah ada peningkatan pemahaman guru dari hasil kegiatan yang dilakukan.

\section{Saran}

Saran yang dapat diberikan antara lain:

1. Guru dapat terus meningkatkan pemahaman tentang ruang sejarah (history room) sebagai media pembelajaran sejarah dengan berbagai cara, misalnya dengan membaca buku, mengikuti aktif dan mengembangkan kegiatan di MGMP dan mengikuti kegiatan pengembangan profesi guru lainya.

2. Program Studi Pendidikan Sejarah FKIP UM Metro dapat terus membatu guru dalam meningkatkan pemahaman guru dan siswa tentang pemanfaatan ruang sejarah (history room) sebagai media pembelajaran sejarah.

3. Permasalahan yang muncul dapat dijadikan dasar untuk penelitian bagi guru atau dosen guna meningkatkan kualitas pembelajaran sejarah terutama dalam mengelola dan memanfaatkan ruang sejarah (history room) dalam membatu mengembangkan pembelajaran sejarah.

\section{DAFTAR PUSTAKA}

Anggara, Boyi. (2007). Pembelajaran Sejarah yang Berorientasi pada Masalah-masalah Sosial Kontemporer. Makalah disampaikan dalam Seminar 
Nasional Himpunan Mahasiswa

Sejarah Se-Indonesia

(IKAHIMSI).Universitas Negeri

Semarang. Semarang

Hamid, Abd. Rahman. (2014).

Pembelajaran Sejarah.

Yogyakarta. Ombak.

Hidayat, Bobi. (2015). Profil Program

Pengalaman Lapangan (PPL)

Mahasiswa Program Studi

Pendidikan Sejarah pada SMP di

Metro. HISTORIA Volume 3, Nomor

2, Tahun 2015

Kochhar, S.K. (2008). Teaching of History. Diterjemahkan oleh Purwanta \& Novita Hardiwati. Jakarta. Gramedia Widiasarana Indonesia

Ali, R.Moh. (2005). Pengantar Ilmu Sejarah Indonesia. Yogyakarta. Lkis Yogyakarta

Supriatna, N. (2007). Konstruksi Pembelajaran Sejarah Kritis. Bandung: Historia Utama

Widja, I Gede. (1989). Dasar-dasar Pengembangan Strategi Serta Metode Pengajaran Sejarah. Jakarta. Depdikbud Direktorat Jendral Pendidikan Tinggi. 
Pengenalan Ruang Sejarah (history room)..., Bobi Hidayat, 95-102 